\title{
Exploring Teaching Profession from a Sociological Perspective: Evidence from Turkey
}

\author{
Serkan Ünsal ${ }^{1}$, Reyhan Ağçam ${ }^{1, *}$, Fahrettin Korkmaz ${ }^{2}$ \\ ${ }^{1}$ Faculty of Education, Kahramanmaraş Sütçü İmam University, Turkey \\ ${ }^{2}$ Ministry of Education, Turkey
}

Copyright $(2017$ by authors, all rights reserved. Authors agree that this article remains permanently open access under the terms of the Creative Commons Attribution License 4.0 International License

\begin{abstract}
Taking into consideration the teachers' direct influence on students' educational life and indirect influence on the community life, the present study aims to reveal perspectives of sociologists, who study human social relationships and institutions, toward teaching profession. Data were collected from 20 sociologists working in educational institutions in Turkey through a semi-structured interview, and analysed using quantitative and qualitative methods under the supervision of three experts (an education programme developer, an educational sociologist, and a member of faculty of education). Findings of the study demonstrated that relatively more professional and technical aspects of teaching are perceived inferior to personal and psychological characteristics of teachers, and that it is still evaluated as a reliable and divine profession despite negative perceptions about it. Financial security, professional satisfaction and vacation time were reported as positive aspects of the profession while exhaustiveness, low prestige and low quality of the profession as negative aspects. As a conclusion, it tends to lose its professional prestige and reliability, and teachers are faced with a variety of problems triggered by different factors in Turkey. The study concludes with possible reasons for the problems in concern, and practical implications to overcome them.
\end{abstract}

Keywords Teaching Profession, Professional Prestige, Sociological Perspective

\section{Introduction}

Sociology is a discipline which investigates an event or phenomenon with a more pluralistic approach using the insights gained by such other disciplines as education, history, law, politics and psychology. Thereby, it could produce a more realistic and complex tool to gain a better understanding of the complicated structure of the social events. Education plays a significant role in the progress of a country. A common goal of educational systems might be identified as to raise qualified and equipped individuals needed in society. Not surprisingly and undoubtedly, raising individuals in concern requires teachers to have necessary content and pedagogical knowledge. In that vein, Ingersoll and Perda [1] identify teachers as the backbone of a school, and it is declared by Center for Education National Research Council (NRC), teaching is a long-term and challenging profession with long-term influences on both students and societies, and a continuous research which aims to improve teacher qualifications is strongly needed.

Pursuant to the Turkish State Personnel Law (Act N. 657), teachers are the professional group that performs all educational services (Yaman et al., [2]) acknowledging that teaching is a special profession that is charged with educational services of the state and administrative services related to them, and that qualifications that teacher candidates are supposed to own in terms of world knowledge, content-specific knowledge, and pedagogic knowledge are determined/ identified by the Ministry of National Education. Accordingly, as cited in Çelikten et al. [3], teaching was identified as a profession that requires specialization in the act, and qualifications teachers are supposed to own could be listed in two groups as personal qualifications and professional qualifications. The authors suggest that the former requires treating students equally, sensitiveness to students' needs and interests, being able to solve the problems using scientific methods, and to predict and interpret the direction of the social change while the latter involves teachers to have sufficient content knowledge, to be able to plan educational procedures effectively, and to have effective time management skills, to be able to track changes in students, and to have sufficient world knowledge by following developments that occur both in his/ her profession and in the world. In line with the above-mentioned qualifications, teachers are also expected to have good communication skills both with students and parents, to establish empathy with them, to be and remain enthusiastic about their job, to be able to choose appropriate methods and techniques in their teaching, and to refresh 
themselves following the latest professional developments.

Özoğlu et al. [4] notify that no satisfactory improvement have been realized even though several significant educational reforms were introduced in Turkey in the last decade (e.g. budget increase). Considering the fact that teachers are the most significant factor that affects the quality of education and student achievement, we are of the opinion that the status of teaching profession should be improved in order to improve the quality of education. In this regard, Hargreaves et al. [5] advocate that public opinion, local and national media, government's perspective toward teaching profession (teacher recruitment/ employment, protection of teacher rights, providing self-respect/ self-image, boosting teachers' morale, and improving the quality of educational settings) are the factors that affect status of teaching profession. In his recent study on education unions' perspective on teachers and teaching profession, Symeonidis [6] concludes that the status of teaching profession, at socio-cultural and economic contexts, is closely related to teachers' job security, income and working conditions, opportunities of professional development, professional autonomy, and quality of education. All in all, status of teaching tends to decline especially in the European countries due to economic crises. Besides, the literature review demonstrates that income and working conditions of teaching profession are the most important criteria for self-image and status of teaching profession. The teachers' freedom of expression, becoming a member of a union, and rights of organization and collective bargaining affect their status in different ways. Özoğlu et al. [4] identify the factors that affect status of teaching profession as (i) economic return of the profession (the higher the income, the higher the status of the profession), (ii) educational period required by profession (the longer the period, the higher the status of the profession), (iii) working conditions (authority and autonomy assigned to teachers), (iv) press interest in teaching profession (how and to what extent the profession appears in media), and (v) development of professional standards (identification of admission and dismissal criteria of the profession).

In the early 1990s, several regulations were released to overcome the imbalanced distribution of teachers in urban and suburban areas in Turkey. Namely, the prerequisite of 'graduation of the undergraduate programme of classroom teaching' was abolished by the Board of Education and Discipline abolished to meet the need for classroom teachers. As a result, the students graduating from such faculties as arts and sciences, and agriculture were nominated as classroom teachers to the schools in suburban areas. In addition, the Teacher Election Exam, which was held with the aim of assessing qualifications of teacher candidates, was abolished (Mete, [7]). During that period when the number of classroom teachers increased and the educational quality in decreased, the belief that one who fails to perform any profession could/ should become a teacher became widespread in the country. In a similar vein, as cited in
Tartuce et al. [8], Jesus [9] draws attention to the fact that many people are engaged in teaching that have no specific training or professional preparation, or are inadequately prepared, and that this situation has contributed to the stereotype that "anyone can be a teacher" in which "anyone" implicitly means lacking in qualifications. The researcher also complains that,

Many of them enter the teaching profession in a transitory way; or put another way, they did not choose to carry out a previously established project, but entered it as a provisional alternative profession, or the only feasible one at a particular moment in time, which might result in a lack of commitment, thus contributing to establishing the social image of a secondary profession (p. 192).

Both incidents revealed that the status of teaching profession is significantly decreased. In line with them, the majority of other related studies reported similar results, and concluded that status of teaching profession should be improved (Bilici, [10]; Doğan, [11]; Bek, [12]; Hargreaves et al., [5]; Özbek et al., [13]; Özoğlu et al., [4]). Studying status of teaching as a profession, Ingersoll and Merill ([14]) assert that prestige and status seem very hard to empirically assess because they are highly subjective; however, considering the results of the general social survey conducted by US Census Bureau on public evaluation of occupational prestige, they suggest that teaching is less prestigious than such other traditional professions as law, medicine, and engineering. In addition, based on the report released by the Bureau of Labor Statistics in 2008, they remind that the average annual salaries of teachers revealed far below those of traditional professionals, such as college professors, scientists, pilots, and lawyers. Taking into consideration the related results and the factor of economic return of the profession mentioned by Özoğlu et al. [4], it might be concluded that professional prestige and income of the professions are positively correlated. So, the low social status of teaching as a profession might be attributed to the fact that teachers are paid relatively lower salaries than most of other traditional employees. Likewise, in a more recent study, Monteiro [15] attributes the problem to the fact that teaching is viewed as an easily accessible profession with lower income and restricted autonomy, and that its outcomes (especially successful outcomes) cannot be clearly identified. He also lists the other factors decreasing its status as irregularities in schools, excessive class sizes, intensive curricula, shortage of resources, and insufficient or negative working conditions. Kavcar [16] underlines that the problem is mostly triggered by the politicians' practices on education, which are exceedingly indifferent and flippant. According to him, people who are oblivious of the goals of Turkish National Education, and who do not know how the programme should be organized work as teachers in Turkey. Akyüz [17] proposes that teaching attracts talented individuals, and gains power and prestige once teachers are paid well enough to be able to live well, to buy books and journals, and to attend 
national and international tours that contribute to their personal and professional development. Otherwise, he notes, they are likely to become alienated from their job and their professional performance decreases. In a similar vein, Bali [18] complains that college teaching in India lost its social prestige in the post-Independence period due to low salaries, lack of autonomy and control over their working conditions, virtual lack of authority in various decision-making processes, and poor working conditions and environment. Lastly, Ünsal and Bağçeci [19] investigated views of teachers working at public and private schools on professional image and influential factors, and reported that teacher qualifications, and status and prestige of teaching profession were evaluated inadequate by the teachers.

Based on the results yielded in previous research, the present study aims to explore sociologists' beliefs about teaching profession. Accordingly, the following research questions were developed.

Q1. What are the sociologists' beliefs about teaching profession in general?

Q2. What are the sociologists' beliefs about pros and cons of teaching profession?

Q3. What are the sociologists' beliefs as to how teaching profession is perceived in society?

Q4. What are the sociologists' beliefs about the most significant problems of teaching profession?

The following section describes and outlines the methodological structure of the study providing demographic information about the participants, and introducing data collection tool and data analysis.

\section{Methods}

Phenomenological method was adopted in analysing data collected from 20 sociologists who were recruited through purposive sampling. An equal number of male and female sociologists took part in the current research. At the time of the study, 7 out of 10 female sociologists held BA degree and 3 held MA degree while only one of the male sociologists held MA degree. It is noteworthy that all the participants studied Sociology at state universities in Turkey. Female sociologists had 5 years of professional experience and their male colleagues had 7 years of professional experience. Lastly, the mean age was calculated 34 and 37 for female and male sociologists, respectively.

In the phase of data collection, a question pool was created by the researchers for forming a semi-structured interview form. The expert opinion was elicited from three faculty members working at the Department of Educational Programmes and Instruction at a state university in Turkey training in order to test the expediency of the questions. One of the experts is specialised in educational programme development while the others in educational sociology, and the interview form was finalized based on their feedback on the questions. At the time of the study, they had been teaching such courses as Philosophical Foundations of Education, Teacher Training, and Turkish Educational System at graduate and undergraduate levels. The form in concern consisted of 7 questions (3 for eliciting demographic info of the participants, and 4 open-ended for eliciting their opinions about teaching profession). It is significant to note that the administration of the interview was not restricted to the workplaces of the participants with the aim of creating a setting whereby they could express themselves comfortably.

The data elicited from the above-mentioned participants were computerized, read and coded by the researchers, and the themes were created based on the codes using the content analysis technique. During the coding process, expert opinion was obtained from a faculty member specialized in qualitative research for the sake of validity and reliability of the data. The correspondence between codes and themes was measured .82 based on the following formula developed by Miles and Huberman [20] (Number of agreements / (Number of agreements + Number of disagreements) $\mathrm{x}$ 100). Findings of the study and related discussion on them are presented in the following section.

\section{Results and Discussion}

The first question of the survey investigated the sociologists' perceptions on the features of teaching profession. Their responses indicated that they view the profession from three different perspectives as pedagogical, personal/ psychological, and social perspectives. Table 1 illustrates the frequency distribution of the codes.

Table 1. Sociologist views on features of teaching profession

\begin{tabular}{|c|c|c|}
\hline Themes & Codes & $f$ \\
\hline \multirow{3}{*}{$\begin{array}{l}\text { Features of } \\
\text { teaching } \\
\text { profession }\end{array}$} & Teaching from pedagogical perspective & 7 \\
\hline & $\begin{array}{l}\text { Teaching from personal/ psychological } \\
\text { perspective }\end{array}$ & 10 \\
\hline & Teaching from social perspective & 4 \\
\hline
\end{tabular}

As seen in Table 1, teaching was mostly reported from personal/ psychological (10 times), 7 times from pedagogical perspective, and least from social perspective. The following extracts are intended to exemplify the perspectives in question.

It is a profession that requires developing empathy with students in order to understand their opinions and feelings and being good-humoured and patient. (P1) (Pedagogical and personal/ psychological perspectives)

It is a profession that requires leadership, class management, objectivity towards students, and having sufficient content knowledge. (P2) (Pedagogical perspective)

It is interestingly seen that relatively more professional and technical aspects of teaching are perceived inferior to personal and psychological characteristics of those who 
perform it as a job. Namely, such features as being sympathetic, affectionate, and having a good sense of humour were reported more frequently than having instructional competence or having good content knowledge. Hence, it might be concluded that more significance is attached to personal and psychological characteristics of the teachers than how effectively they teach subject matters.

The second question scrutinized the sociologists' opinions about positive and negative aspects of teaching as a profession. Three codes were created for each theme based on their responses and displayed in Table 2 .

Table 2. Sociologists' opinions about pros and cons of teaching

\begin{tabular}{|l|l|c|}
\hline Themes & \multicolumn{1}{|c|}{ Codes } & $f$ \\
\hline \multirow{4}{*}{ Pros } & Financial security & 1 \\
\cline { 2 - 3 } & Professional satisfaction & 13 \\
\cline { 2 - 3 } & Vacation time & 5 \\
\hline \multirow{3}{*}{ Cons } & Exhaustiveness & 4 \\
\cline { 2 - 3 } & Low prestige & 8 \\
\cline { 2 - 3 } & Low quality of the profession & 4 \\
\hline
\end{tabular}

As depicted in Figure 1, the participants reported financial security, professional satisfaction and vacation time as positive aspects of teaching profession, and exhaustiveness, low prestige and low quality of the profession as its negative aspects.

One of the noteworthy findings of the study is that professional satisfaction was overwhelmingly reported by sociologists among all aspects of teaching profession. Namely, $65 \%$ of them believe that teachers are professionally satisfied with their job, or that they perform their job for professional satisfaction. This particular finding overlaps the belief that teaching is distinguished from other professions in Turkey since teachers state they go to school, not to work when they leave home. However, the OECD Teaching and Learning International Survey (TALIS) 2013 results have proved rather different as job satisfaction of Turkish teachers was measured below the TALIS average.

Table 3. Annual working time of teachers in OECD countries

\begin{tabular}{|c|c|c|}
\hline Country & $\begin{array}{c}\text { Annual Working Time } \\
\text { (Hour) }\end{array}$ & $\begin{array}{c}\text { Summer Break } \\
\text { (Week) }\end{array}$ \\
\hline Cz. Republic & 1696 & 8 \\
\hline Denmark & 1680 & $7-8$ \\
\hline Germany & 1793 & 6 \\
\hline Iceland & 1800 & 11 \\
\hline Portugal & 1456 & 12 \\
\hline Spain & 1425 & 11 \\
\hline Sweden & 1767 & 10 \\
\hline Turkey & 1816 & 9 \\
\hline OECD Ave. & 1675 & 9.7 \\
\hline
\end{tabular}

Surprisingly, on the other hand, financial security and vacation time was mentioned much less frequently as an advantage of the professional. Based on the statistical data released by the Ministry of Labour and Ministry of Finance, the unemployment rate in Turkey reached up to $13 \%$ in 2017 , and only $12.5 \%$ of the working population was constituted by civil servants including teachers in 2016 . The social and financial rights and facilities the teachers have (e.g. a regular income, health security, two-month summer break, rights to unionize and strike, and etc.) might be considered to account for the participants' responses on the pros of the teaching profession. Nonetheless, it is significant to note that Turkish teachers have shorter summer break and less financial income than most of their European colleagues. Table 3 presents annual working time and summer break of teachers in certain OECD countries.

Voicing exhaustiveness as one of the cons of the profession might be attributed to the teacher responsibilities out of working hours of a typical civil servant, which is identified 40 hours weekly in the constitutional law (Act N. 657), such as hall monitoring, parental meetings, supervision of student clubs, grading project assignments, uploading them on the related e-systems, and realising other tasks assigned by the school administration. In line with Kuzgun [4], a female sociologist with 4 years of professional experience states,

When performed with love, teaching profession is so fun. Imagine that you can shape the characters of the individuals. The negative side is to take work home; thus, most of the teachers go on working when they are supposed to rest, and spend less time with their family. (P3)

Concerning with the negative aspect of teaching profession, a male sociologist with 6 years of experience mentions that teachers get a raw deal from the society stating,

Teachers want to be beneficial to the society, and to make people happy. When they fail to do so despite their all efforts, they fail to receive respect from the society. They can even be exposed to violence.

Approximately half of the participants identified low prestige as a negative aspect of teaching profession, confirming Akyüz [18], Ingersoll and Merill [15], Özoğlu et al. [7], Monteiro [16], and Ünsal and Bağçeci [19]. So, this particular finding of the present study might be attributed to insufficient financial facilities provided to the teachers along with irregularities in schools, excessive class sizes, intensive curricula, shortage of resources, insufficient or negative working conditions, and virtual lack of authority in decision-making processes, as indicated in the previous studies in concern. Lankford et al. [21] attribute it to the problems encountered in teacher training, students' low performance on international exams in the US, lack of qualified documentation, and low teacher qualifications. Cohen [22], on the other hand, advocates that this is caused by direct government intervention in curriculum. 
Exhaustiveness and low quality of the profession were the other aspects identified negative by the sociologists in the current research; however, they seem to be factors that trigger loss in professional prestige of teaching rather than individual negative aspects of it particularly when taking the results of the previous studies into account. All in all, it has been demonstrated that positive aspects of the teaching profession were reported slightly more frequently than the negative ones.

The aim of the third question was to elicit the sociologists' perceptions as to how teaching profession is perceived by the society. In accordance with their responses, it could be claimed that teaching has more positive connotations than negative ones. That is, positive codes were reported 16 times while negative codes were mentioned 10 times. The extract taken from the response of a male sociologist with 7 years of experience seems to exemplify this case.

Despite everything, it has remained a reliable profession by the society since teachers are believed to raise the individuals in a good manner (P10).

The frequency distribution of the perceptions of the society about teaching profession is illustrated in Table 4.

Table 4. Sociologists' opinions about the perceptions of the society on teaching profession

\begin{tabular}{|l|l|l|}
\hline \multicolumn{1}{|c|}{ Themes } & \multicolumn{1}{|c|}{ Codes } & $f$ \\
\hline \multirow{4}{*}{$\begin{array}{l}\text { Positive } \\
\text { perceptions }\end{array}$} & Respected & 5 \\
\cline { 2 - 3 } & Shaping people's future & 3 \\
\cline { 2 - 3 } & Reliable & 3 \\
\hline \multirow{3}{*}{$\begin{array}{l}\text { Negative } \\
\text { perceptions }\end{array}$} & Divine & 5 \\
\cline { 2 - 3 } & Ordinary & 2 \\
\hline & Disrespected & 1 \\
\hline & Unreliable & 1 \\
\hline
\end{tabular}

The responses have indicated that respect attached to teaching profession by the society appears to split the participants into two groups. Namely, 6 sociologists believe that it is viewed as a disrespected profession while 5 sociologists believe the opposite. This might be considered an optimistic finding especially when taking previous findings reported by Karamustafaoğlu and Özmen [23] and Semerci et al. [24] into account. Those who reported that it is viewed as an ordinary, unreliable and useless profession by the society remained minority. One of the sociologists with 4 years of experience attributes the negative perceptions about teaching profession to the fact that it has been made ordinary and simplified especially in recent years, and there seems to be no difference between teachers and other civil servants. The finding perfectly fits with those previously reported in Özoğlu et al. [7] and Hargreaves et al. [8]. Nonetheless, responses of the participants revealed that teaching is still evaluated as a reliable and divine profession, and that teachers are believed to shape the future of the society. This particular finding approves the results of the 2015 survey conducted by WIN/Gallup International in 60 countries that revealed teachers are the mostly trusted professional group in Turkey $(86 \%)$, followed by healthcare and military personnel $(81 \%$ and $74 \%$, respectively). Accordingly, a female sociologist with 2 years of experience warns that teaching profession should regain its prestige and respect in the presence of society shifting from passive to active status (P16).

Lastly, the sociologists were asked their opinions about the most significant problems encountered in teaching profession. The problems identified by them were divided into three groups, as shown in Table 5.

Table 5. Sociologists' opinions about most significant problems of the teaching profession

\begin{tabular}{|c|c|c|}
\hline Theme & Codes & $f$ \\
\hline \multirow{2}{*}{$\begin{array}{c}\text { Problems of } \\
\text { teaching profession }\end{array}$} & Teacher-derived problems & 9 \\
\cline { 2 - 3 } & Bureaucracy-derived problems & 5 \\
\cline { 2 - 3 } & Society-derived problems & 6 \\
\hline
\end{tabular}

The problems reported by the sociologists could be listed as teacher-derived problems, bureaucracy-derived problems, and society-derived problems. The following extracts are intended to illustrate each group.

Teachers get away from idealism, and they don't value their own profession. (P7) (Teacher-derived)

Some students are aimless. They come to school just to graduate from it. Parents are expecting everything from teachers and becoming indifferent to their children's education. They tend to put the blame on teachers in any negative situation. (P11) (Society-derived)

Families are expecting miracles from teachers. They attribute possible successes to themselves, and failure to the teachers. (P8) (Society-derived)

People who do not any aptitude for teaching choose this profession just for its income. So, the graduation standards from faculties of education should be raised. (P13) (Teacher-derived \& Bureaucracy-derived)

These findings are also in line with Ingersoll and Merill [14], Özoğlu et al. [4], Yirci [25], Papadopoulou \& Yirci [26] and Monteiro [15]. More specifically, we could claim that the afore-mentioned problems encountered in Turkey mostly stem from the fact that the policies for teacher training and recruitment are planned and organized by administrative authorities rather than those who are specialized in education. In a similar manner, Bassey [27] argues that government intervention has already re-aligned the education system to the needs of the 21 st century, and that it is counter-productive, being restrictive of children's development and destructive of teacher morale.

The following section provides practical implications that might be suggested in the light of the present findings. 


\section{Conclusions}

Our study has yielded similar findings previously reported in various settings. Namely, it has indicated that teaching tends to lose its professional prestige and reliability, and teachers are faced with a variety of problems triggered by different factors in Turkey. In order to overcome teacher-derived and bureaucracy-derived problems, and especially to improve professional status of teaching, Bilici [10] suggests that teacher candidates should be elected among individuals who are really willing to perform this profession, solutions should be created/ produced to its financial and social problems, teachers should be raised in a way they could effectively use educational technologies, and activities enabling teachers to regenerate themselves should be organized. Likewise, Özbek et al. [13] propose that social and economic conditions of teaching profession should be improved so that it gains a preferable status, and the society should be informed about teaching profession in order to improve its status. The following are the solutions to increase status of teaching profession by Özoğlu [28].

- Ministry of National Education should handle teacher surplus by balancing supply and demand in collaboration with other state institutes and organizations.

- A more holistic approach should be adopted in offering solutions to the problems related to teacher training.

- Organizations that enable teachers to develop professionally should be held, and necessary supervision should be provided.

- The perception that "teaching can be performed by anyone" should be changed/ eliminated, and its admission requirements should be raised.

- Teachers should be assigned sufficient autonomy in content teaching.

- Teacher nomination should be planned in a more healthy way.

Bassey [26] strongly recommends stopping ministerial intervention, restoring autonomy to schools and teachers, and reducing monitoring of performance to the minimum needed to ensure that the government of the day can know whether it needs again to intervene in a particular period. He goes on to state that teachers should be trusted - on the grounds that they know best what their pupils need.

Being in full agreement with the suggestions in concern, the researchers of the present survey strongly recommend that teacher training programmes and teacher recruitment should be organized and implemented by the authorities who are specialized purely in education and educational sciences in the country. It is also recommended that teachers should endeavour to get involved in the decision-making process about educational and professional concerns by using their constitutional rights (e.g. rights to unionize and strike) when required. Besides, the following precautions might be recommended to stakeholders of teacher training and employment process.

- Economic improvements should be introduced to increase social status of teaching profession. Namely, financial income of the teachers should be increased to such amount as could be equal to that of their colleagues in other OECD countries. Likewise, their working conditions should be enhanced (e.g. decreasing working hours to the TALIS average).

- In-service teacher training programmes might be introduced to improve teacher qualifications and maintain their enthusiasm for their job.

- In order to eliminate the fallacious beliefs that teaching is an easy job to perform and that teachers get 3-month summer break, the society should be informed about the significance of teachers with regard to education and society through organizations such as seminars, conferences or panels, or public service announcements

- Teachers might be recommended to refresh themselves tracking developments around them, and attending events organized for professional development. They might also be suggested to establish and maintain empathy with various segments of the society in order to increase social status of their job.

This study is confined to the investigation of the sociologists' beliefs about teaching profession, and it revealed that the society has certain negative perceptions about it. So, it might be furthered to explore the ways how it could regain its prestige in order to become a preferable, respected and reliable profession. Another study might be conducted on teachers' own beliefs about their profession, and their opinions might be elicited as to how cons of their profession should be eliminated. Finally, perceptions of sociologists living in other countries of different socio-economic status on teaching profession might be investigated, and its results might be compared with the ones revealed in this study in order to see whether they significantly differ from each other.

\section{REFERENCES}

[1] R. M. Ingersoll \& D. Perda. The status of teaching as a profession. In J. Ballantine and J. Spade (Eds.), Schools and Society: A Sociological Approach to Education, 106-118. Los Angeles: Pine Forge Press, 2008.

[2] E. Yaman, H. Yaman\& A. Eskicumal1, A. Socio-economic status of teaching profession. Sakarya University Journal of Faculty of Education, 2, 2001.

[3] M. Çelikten, M. Şanal, \& Y. Yeni. Teaching profession and its characteristics. Erciyes University Journal of Institute of Social Sciences, 19(2), 207-237, 2005.

[4] M. Özoğlu, B. S. Gür\& A. Altınoğlu. Teaching in Turkey and World. Ankara, 2013. 
[5] L. Hargreaves, M. Cunningham, A. Hansen, D. McIntyre, \& C. Oliver. The status of teachers and the teaching profession in England: Views from inside and outside the profession. The Chancellor, Masters and Scholars of the University of Cambridge, 2007.

[6] V. Symeonidis. The status of teachers and the teaching profession: A study of education unions' perspectives. Education International Research Institute, Belgium, 2015.

[7] Y. A. Mete. Policies of Teacher Nomination based on Equality of Opportunity -Objective Analysis/ Subjective Evidences. Unpublished PhD dissertation, Kocaeli University: Kocaeli, 2009.

[8] G. L. B. P. Tartuce, M. M. R. Nuneso, \& P. C. A. De Almeida. Secondary school students and the attractiveness of the teaching career in Brazil. Cad. Pesqui, 40(140), 2010. doi: http://dx.doi.org/10.1590/S0100-15742010000200008

[9] S. N. Jesus. Desmotivação e crise de identidade na profissão docente. Revista Katálysis, Florianópolis, 7(2): 192-202, 2004.

[10] V. Bilici. Teacher of 2000. Educational Management in Theory and Practice, 5(5), 45-48, 1996.

[11] C. Doğan. Policies for primary school teachers training and related problems in Turkey. Bilig: Journal of Social Sciences of the Turkish World, 35, 133, 2005.

[12] Y. Bek. Sociological and Professional Roles, and Status of Teachers. Unpublished MA Dissertation. Trakya University, Institute of Social Sciences. Edirne Edirne, 2007.

[13] R. Özbek, M. Kahyaoğlu\& N. Özgen. Evaluating prospective teachers' views on teaching profession. Journal of Social Sciences, 9(2), 2007.

[14] R. M. Ingersoll \& E. Merrill. The status of teaching as a profession. In J. Ballantine and J. Spade (Eds.), Schools and Society: A Sociological Approach to Education, 185-198. 4th Ed. CA: Pine Forge Press/Sage Publications, 2011.

[15] R. A. Monteiro. The Teaching Profession Present and Future. New York: Springer, 2015.
[16] C. Kavcar, C. The Problem of Qualified Teachers. Education and Science, 5(28), 1980.

[17] Y. Akyüz, Y. Teacher's Effect on Social Change in Turkey. Doğan Publishing Company, Ankara, 1978.

[18] A. P. Bali. College Teachers: Challenges and Responses. Northern Book Centre: New Delhi, 1986. M. B. Miles \& A. M. Huberman. Qualitative Data Analysis. Sage Publication, 1994.

[19] S. Ünsal\& B. Bağçeci. Teachers' views on professional image and influential factors. Journal of Human Sciences, 13(3), 3905-3926, 2016.

[20] M. B. Miles \& A. M. Huberman. Qualitative Data Analysis. Sage Publication, 1994.

[21] H.,Lankford, S. Loeb, A. Mceachin, \& J. Wyckoff., J. Who enters teaching? Encouraging evidence that the status of teaching is improving, Educational Researcher December. 43(9). 1-56, 2014.

[22] M. R. Cohen. The Low Status of Teachers: A Global Epidemic?, 2012.

[23] O. Karamustafaoğlu, O, \& H. Özmen. A study on the prestige of teaching profession from the perspective of prospective teachers and society. DED, 2(6), 35-49, 2004.

[24] Ç. Semerci, N. Semerci, A. Eliüşük. \& E. Kartal. Teachers' views on professional agenda of teaching (Sample of Bartın). Bartın University Journal of Faculty of Education, 1(1), 2012.

[25] R. Yirci. Barriers to Teacher Professionalism and Suggestions. for Solution. Ahi Evran University Journal of Kurşehir Faculty of Education, 18(1), 503-522, 2017

[26] V. Papadopoulou, \& R. Yirci. Rethinking Decentralization in Education in terms of Administrative Problems. Educational Process: International Journal, 2 (1-2), 7-18, 2013.

[27] M. Bassey. Teachers and government: A history of intervention in education. The Association of Teachers and Lectures, 2005.

[28] M. Özoğlu. Problems of Teacher Training System. Ankara: Research Foundation of Politics, Economics and Society, 2010. 